\title{
O OLHAR PUBLICITÁRIO SOBRE A HIPÓTESE DE NEWSMAKING
}

Márcia Pillon Christofoli

\section{RESUMO}

O presente estudo tem como objetivo adaptar a hipótese de newsmaking, utilizada em pesquisas na área de jornalismo, ao mercado publicitário. As rotinas de trabalho de uma agência de publicidade dificultam o processo de lugarização dos sujeitos que nela atuam, bem como a construção dos vínculos destes profissionais com as organizações. Nesta situação, o processo de comunicação adquire um papel fundamental no estabelecimento das relações.

Palavras-Chave: Hipótese de Newsmaking; Atendimento; Comunicação

\section{THE ADVERTISING VIEW ABOUT NEWSMAKING HYPOTHESIS}

\begin{abstract}
The present study aims to adapt newsmaking hypothesis, which is used in Journalism researches, to advertising market. The routines of work in an advertising agency hamper the process of 'placing' people who work there, besides hampering also the bond building between employees and organizations. In this situation, communication process is essential to relationships.
\end{abstract}

Keywords: Newsmaking Hypothesis; Attendance; Communication 


\section{Introdução}

Iniciamos este artigo destacando a importância e a evolução da publicidade e da propaganda ${ }^{1}$, no contexto sócio-econômico atual. De acordo com Sampaio (1999, p. 29), ela adquire um papel significativo como impulsionadora da economia, já que, "de um lado, funciona como elemento vital para que as empresas conquistem mais consumidores e expandam suas atividades, e, de outro, para que os consumidores estejam melhor informados e possam escolher adequadamente o que consumir".

Ou ainda, conforme Castro (2008, p. 41), "a ação de divulgar, enaltecer, celebrar algum produto, tema ou serviço é hoje uma prática comum entre seres socialmente organizados, dentro de um complexo quadro de relações socioculturais".

No processo de criação e produção de campanhas publicitárias, temos, numa ponta, o anunciante (ou cliente), que tem algo a comunicar e a intenção de convencer o consumidor, que é a outra ponta deste processo. Em muitos casos, a mediação de todo este trabalho se faz através de uma agência de propaganda. A função principal da agência é aconselhar e assistir o cliente em suas necessidades de comunicação com o mercado, ou seja, "tudo ligado à comunicação mercadológica, inclusive propaganda" (SANT'ANNA et al., 2010, p. 301).

A estrutura de uma agência é formada pelas áreas de Atendimento, Planejamento, Criação, Mídia, Produções Gráfica e Eletrônica, e a equipe Administrativa/Financeira. Esta estrutura pode variar de agência para agência, conforme seu tamanho, que normalmente é determinado pela verba publicitária de seus clientes, mas este ainda é considerado o modelo mais tradicional.

O processo se inicia com o profissional de atendimento que, após uma reunião com o cliente, repassa para todos os outros departamentos quais as suas necessidades. Esta solicitação é feita através de um briefing, documento que contém todas as informações necessárias para a realização do trabalho. É do atendimento também a responsabilidade de supervisionar e coordenar o desenvolvimento da campanha - desde a primeira solicitação do cliente até a sua produção, instalação e veiculação - ou seja, até atingir o público final.

De todo este processo, o que destacaremos, neste artigo, são as relações do atendimento com os seus públicos, bem como uma das principais tarefas deste profissional, a

\footnotetext{
${ }^{1}$ Para muitos pesquisadores e profissionais, e em muitos estudos, os conceitos de publicidade e propaganda são usados distintamente, mas neste trabalho serão tratados como sinônimos.
} 
elaboração de um briefing, isto é, um documento que dê condições para que todos os departamentos envolvidos na criação e produção da campanha possam realizar um trabalho satisfatório ao cliente.

Usaremos, portanto, o termo cliente para denominar as organizações que possuem algum tipo de relação com uma agência de propaganda (denominada de agência); relação que é intermediada pelo executivo de contas ou profissional de atendimento (denominado atendimento). Ou seja, é a partir da solicitação do cliente, de uma campanha ou peça publicitária, que o atendimento elabora o briefing e estabelece suas relações de trabalho.

De acordo com Sampaio (1999), os sujeitos deste processo são conceituados da seguinte forma:

\begin{tabular}{|l|l|}
\hline Anunciante & $\begin{array}{l}\text { Também chamado de cliente, é a empresa, pessoa ou instituição que faz uso } \\
\text { da propaganda para resolver algum problema de comunicação e, com isso, } \\
\text { atender a uma finalidade específica e definida - geralmente a venda de } \\
\text { produtos e serviços. }\end{array}$ \\
\hline Agência de & $\begin{array}{l}\text { Empresa especializada na técnica e na arte da propaganda, reunindo, para } \\
\text { isso, tecnologia específica e corpo de profissionais de diversas } \\
\text { especializações, que se estruturam em departamentos (atendimento, } \\
\text { planejamento, criação, mídia, pesquisa etc.) com funções específicas. } \\
\text { Assessora o anunciante em todas as suas necessidades de propaganda e } \\
\text { executa tarefas necessárias à sua realização, coordenando o trabalho de } \\
\text { fornecedores e produtoras, e intermediando o relacionamento cliente-veículo. }\end{array}$ \\
\hline Atendimento & $\begin{array}{l}\text { O atendimento é o setor que presta assistência aos clientes [...] O } \\
\text { relacionamento agência-cliente é função central do Atendimento que, na } \\
\text { maior parte dos casos, também é responsável pela tarefa de planejamento de } \\
\text { comunicação publicitária dos clientes sob seus cuidados em conjunto ou não } \\
\text { com as demais áreas da agência. O acompanhamento das tarefas } \\
\text { subsequentes (criação, produção, planejamento de mídia, veiculação e } \\
\text { aferição dos resultados) também é tarefa do Atendimento, que deve manter o } \\
\text { cliente sempre bem informado e obter dele as necessárias análises e } \\
\text { aprovações no decorrer do processo. }\end{array}$ \\
\hline
\end{tabular}

TABELA 1: Conceitos dos sujeitos envolvidos na análise deste artigo.

FONTE: Elaborado pela autora a partir de Sampaio (1999, p. 37; 40; 57-58). 
Sampaio (1999, p. 317) apresenta também o conceito de briefing (resumo, em inglês), como sendo o "documento contendo a descrição da situação da marca ou empresa, seus problemas, oportunidades, objetivos e recursos para atingi-los. Base do processo de planejamento".

Ressaltamos, aqui, a importância de todos os departamentos e profissionais envolvidos na criação de uma campanha publicitária e no funcionamento de uma agência, mas o foco da nossa pesquisa será no atendimento, por se tratar do elo de ligação e de relação entre o mercado, o cliente e a agência. O departamento de atendimento, portanto, é um dos principais canais de comunicação e de interação entre estes públicos.

Sob esta perspectiva, podemos afirmar que é do atendimento a responsabilidade de transformar a informação recebida do cliente em conhecimento para todos os departamentos da agência, sendo, portanto, o responsável por todas as informações que circulam entre cliente-agência e agência-cliente.

Assim, é de acordo com estas rotinas publicitárias que vamos associar o profissional de atendimento à figura do gatekeeper, com o objetivo de adaptar a teoria de newsmaking, utilizada em pesquisas na área de jornalismo, ao mercado publicitário.

Este desafio surge a partir de um projeto de pesquisa que pretende analisar as relações de trabalho estabelecidas entre o profissional de atendimento e seus diferentes públicos (cliente e agência). Sustentamos, como hipótese, o fato de que as rotinas de trabalho de uma agência e a produção de campanhas publicitárias (e seus decorrentes processos de comunicação), dificultam o processo de lugarização ${ }^{2}$, bem como a construção dos vínculos destes profissionais com as organizações em que atuam. Nesta situação, o processo de comunicação adquire um papel fundamental no estabelecimento destas relações.

A teoria de newsmaking será utilizada para a construção de uma metodologia que possibilite alcançar os objetivos e sustentar as hipóteses acima propostos ${ }^{3}$. Ao final deste artigo, pretendemos apresentar um quadro de categorias utilizadas pelo atendimento, para construir o briefing, bem com apresentar um roteiro com as questões que irão nortear as entrevistas em profundidade (que serão realizadas, num outro momento, com profissionais atuantes no mercado).

\footnotetext{
${ }^{2}$ A definição de lugar e não-lugar está exposta no item 2.2, mas podemos adiantar que o processo de lugarização ocorre quando o profissional se identifica com a organização em que atua, quando esta adquire um significado para ele, ou seja, quando se estabelece uma relação de identificação.

${ }^{3}$ Como detalharemos adiante (item 2.3), as pesquisas de newsmaking se apoiam na observação participante e, em alguns casos, com entrevistas em profundidade.
} 


\section{Pressupostos Teóricos}

\subsection{Comunicação}

Cabe destacar que este estudo entende a comunicação sob uma abordagem humanista ${ }^{4}$. Segundo Wolton (2006; 2010), a essência da comunicação não está do lado das técnicas e de seus usos, mas do lado da capacidade de ligar estas ferramentas técnicas a valores democráticos.

A comunicação é a busca da relação e do compartilhamento. Ela pressupõe respeito ao outro. Nada é mais difícil do que reconhecer o outro como seu igual, sobretudo se não há compreensão. Comunicar é "admitir a importância do outro, aceitar nossa dependência em relação a ele e a incerteza de ser compreendido por ele" (WOLTON, 2006, p. 15); é, em primeiro lugar, uma maneira de se expressar, mas expressar-se não basta para garantir comunicação. É preciso saber se estamos sendo ouvidos e, acima de tudo, se há interesse no que está sendo dito. "Os receptores negociam, filtram, hierarquizam, recusam ou aceitam as incontáveis mensagens recebidas, como todos nós, diariamente. O receptor, que nunca foi passivo, está cada vez mais ativo para resistir ao fluxo de informações" (WOLTON, 2010, p. 18).

Para Morin et al. (2007, p. 42-43),

[...] não devemos confundir comunicação e compreensão, porque a comunicação é comunicação de informação às pessoas ou grupos que podem entender o que significa a informação. Mas a compreensão é um fenômeno que mobiliza os poderes subjetivos de simpatia para entender uma pessoa como uma pessoa que é também sujeito. [...] Há um problema fundamental no mundo da comunicação: não basta multiplicar as formas de comunicação, também é preciso a compreensão.

De acordo com Iasbeck (2010, p. 147):

A comunicação é um processo natural de troca de informações e que pode ser definido em várias intensidades, sob variadas ópticas e dimensões. Não pode, todavia, ficar restrita ao campo técnico das conceituações mecanicistas, sob pena de não explicar (ou camuflar) seus objetivos mais urgentes nas relações humanas: o estabelecimento e a manutenção de vínculos.

O autor cita Marcondes Filho (2008), ao afirmar que "o objetivo maior dos atos comunicativos (e que os motiva sobremaneira), não é tanto o relacionamento em si mesmo, mas o que pode (e deve) resultar desse relacionamento, os vínculos” (IASBECK, 2010, p. 147).

\footnotetext{
${ }^{4}$ Embora durante anos a abordagem técnica e econômica da comunicação tenha dominado as teorias e os estudos.
} 
Informação e comunicação são dois conceitos distintos, embora tenham sido tratados como sinônimos durante, muito tempo. Segundo Wolton (2010, p.12), “a informação é a mensagem. A comunicação é a relação, que é muito mais complexa”. Não basta, portanto, informar para comunicar. A informação precisa ser compreendida pelo outro, para então se estabelecer a comunicação. Assim, entendemos comunicação como a relação emissor/mensagem/receptor (não sendo apenas como transmissão das informações). A comunicação, afirma Wolton (2010, p.11) "é sempre mais difícil, pois impõe a questão da relação, ou seja, a questão do outro. [...] o emissor raramente está em sintonia com o receptor e vice-versa".

\subsection{Lugar e não-lugar}

As relações de trabalho, segundo Fischer (1994, p. 82), se realizam em espaços, ou seja, "dentre os diversos ambientes que compõe a realidade social, os espaços de trabalho ocupam um lugar físico e simbólico".

Assim, a partir na noção de espaço, surge a necessidade de discutir o lugar ocupado pelo atendimento nas suas relações de trabalho. Segundo Augé (1994, p. 77), “o termo espaço, em si mesmo, é mais abstrato que o de lugar, por cujo emprego referimo-nos, pelo menos, a um acontecimento (que ocorreu), a um mito (lugar-dito) ou a uma história (lugar histórico)". O lugar, portanto, é entendido como "conjunto de elementos, coexistindo dentro de uma certa ordem, e do espaço como animação desses lugares, pelo deslocamento de uma força motriz" (AUGÉ, 1994, p. 75).

Para Santaella (2007, p. 164), “o espaço nos aparece de uma variedade de formas e de relações entre espaço e lugar, em que os lugares não podem ser separados de seu contexto de experiência”. Assim, o lugar torna-se identitário, remete a um sentimento de pertencimento. Quando estabelecemos uma relação com o espaço em que nos encontramos, quando estabelecemos vínculos com estes espaços, é que podemos falar em lugar.

Por outro lado, os não-lugares referem-se à falta de relação com o lugar:

Se um lugar pode se definir como identitário, relacional e histórico, um espaço que não pode se definir nem como identitário, nem como relacional, nem como histórico definirá então um não-lugar [...] a supermodernidade é produtora de não-lugares (AUGÉ, 1994, p. 73).

Seguindo a linha de Augé (1994), Bauman (2001, p. 120) utiliza o conceito de espaços vazios, que "são antes de mais nada vazios de significado. Não que sejam sem significado 
porque são vazios: é porque não têm significado, nem se acredita que possam tê-lo, que são vistos como vazios (melhor seria dizer não-vistos)".

\title{
2.3 A hipótese de newsmaking
}

De acordo com Hohlfeldt (2007) e Wolf (2005), o newsmaking está associado ao estudo da sociologia das profissões, neste caso, o jornalismo. "É, portanto, mais uma teoria do jornalismo do que propriamente da comunicação, mas tem sido estudada genericamente sob a perspectiva comunicacional, e vamos aqui manter esta tradição" (HOHLFELDT, 2007, p. 203).

\begin{abstract}
A hipótese de newsmaking dá especial ênfase à produção de informações, ou melhor, à potencial transformação dos acontecimentos cotidianos em notícia. Deste modo, é especialmente sobre o emissor, no caso o profissional da informação, visto enquanto intermediário entre o acontecimento e sua narratividade, que é a notícia, que está centrada a atenção destes estudos, que incluem sobremodo o relacionamento entre fontes primeiras e jornalistas, bem como as diferentes etapas da produção informacional, seja ao nível da captação da informação, seja em seu tratamento e edição e, enfim, em sua distribuição (HOHLFELDT, 2007, p. 203204).
\end{abstract}

A figura do gatekeeper ganha importância nestes estudos, pois ele é o sujeito que tem o poder de filtrar e optar, ou não, pelo uso de determinada informação; "o contexto profissional-organizacional-burocrático circunstante exerce uma influência decisiva nas escolhas dos gatekeepers" (WOLF, 2005, p. 186). Podemos dizer, então, que os processos de produção - as rotinas de trabalho - atuam de forma determinante na seleção das informações.

Com relação aos aspectos metodológicos, as pesquisas sobre newsmaking se apoiam na observação participante. O pesquisador se insere no ambiente a ser estudado, observando e conversando (informalmente ou através de entrevistas), e colhendo os dados da rotina de trabalho dos profissionais envolvidos no processo.

\footnotetext{
O convívio com os pesquisadores é fundamental, porque leva à familiarização com o grupo e às rotinas ali desenvolvidas, numa perspectiva de naturalidade, até o momento em que, tendo-se identificado plenamente com o grupo, deve distanciar-se do mesmo para poder manter o espírito observador e crítico sobre tais práticas, descrevendo-as, analisando-as e eventualmente criticando-as, na constituição do que se poderia denominar de uma etnografia da comunicação (HOHLFELDT, 2007, p. 207).
}

A pesquisa e a abordagem do newsmaking se constituem a partir das relações entre dois aspectos: a cultura profissional; e a organização do trabalho e dos processos de produção.

De acordo com Hohlfeldt (2007, p. 207-208), 
a cultura profissional, nesta perspectiva, é um emaranhado de retóricas e táticas, códigos, estereótipos e símbolos relativos aos meios de comunicação de massa, que criam e mantêm paradigmas profissionais e auto-imagem. As convenções de organização deste trabalho determinam e definem o que seja notícia e legitimam o processo produtivo das mesmas, constituindo o conceito de noticiabilidade, ou seja, [...] o conjunto de requisitos que se exige de um acontecimento para que ele adquira existência enquanto notícia.

Ou ainda, para Wolf (2005, p. 195),

a noticiabilidade é constituída pelo complexo de requisitos que se exigem para os eventos - do ponto de vista da estrutura do trabalho nos aparatos informativos e do ponto de vista do profissionalismo dos jornalistas -, para adquirir a existência pública de notícia.

A noticiabilidade corresponde, portanto, aos critérios pelos quais se escolhe, entre diversos fatos, o que será notícia. Estes critérios são elaborados a partir de valores-notícia, “conjunto de elementos e princípios através dos quais os acontecimentos são avaliados pelos meios de comunicação de massa e seus profissionais em sua potencialidade de produção de resultados e novos eventos, se transformados em notícia" (HOHLFELDT, 2007, p. 208).

Os valores-notícia não podem ser analisados separadamente. É justamente as relações e combinações entre eles que irá determinar a seleção de um fato.

Os valores-notícia são critérios para selecionar, do material disponível para a redação, os elementos dignos de ser incluídos no produto final. [...] funcionam como linhas-guia para a apresentação do material, sugerindo o que deve ser enfatizado, o que deve ser omitido, onde dar prioridade na preparação das notícias a serem apresentadas ao público. Os valores-notícia são, portanto, regras práticas que compreendem um corpus de conhecimentos profissionais que, implícita e muitas vezes explicitamente, explicam e guiam os procedimentos de trabalho redacional (WOLF, 2005, p. 203).

A seguir, apresentamos as cinco grandes categorias em que são agrupados os valoresnotícia $^{5}$, de acordo com Hohlfeldt (2007):

\begin{tabular}{|c|l|}
\hline CATEGORIAS & \\
\hline \multirow{3}{*}{ Substantivas } & $\begin{array}{l}\text { Importância (nível hierárquico dos indivíduos envolvidos; } \\
\text { impacto sobre a nação e o interesse nacional; quantidade de } \\
\text { pessoas envolvidas no acontecimento; relevância e significação } \\
\text { do acontecimento quanto à sua potencial evolução) }\end{array}$ \\
\cline { 2 - 2 } & Interesse (capacidade de entretenimento; interesse humano; \\
\hline
\end{tabular}

${ }^{5}$ Estas categorias serão melhor explicadas no item 3 deste trabalho (Aplicações), mas recomendamos também uma leitura aprofundada nas obras de Wolf (2005, p. 208 - 228) e Hohlfeldt (2007, p. 209 - 214).

INTRATEXTOS, Rio de Janeiro, 4(1): 37-52, 2012. 


\begin{tabular}{|c|c|}
\hline & composição equilibrada do noticiário) \\
\hline \multirow{5}{*}{ Relativas ao produto } & Brevidade (adequação do formato do jornal) \\
\hline & $\begin{array}{l}\text { Condições de desvio da informação (o acontecimento raro é } \\
\text { sempre mais noticiável que o acontecimento comum) }\end{array}$ \\
\hline & $\begin{array}{l}\text { Atualidade/atualidade interna (relação com o tempo do jornal, se } \\
\text { há possibilidade de publicá-lo ou não, em função do dead line } \\
\text { para impressão, por exemplo) }\end{array}$ \\
\hline & Qualidade (qualidade técnica compatível com o nível do jornal) \\
\hline & Equilíbrio (mesclar diferentes temas e abordagens) \\
\hline \multirow{3}{*}{$\begin{array}{l}\text { Relativas aos meios de } \\
\text { informação }\end{array}$} & $\begin{array}{l}\text { Bom material visual x texto verbal (um bom texto deve ter uma } \\
\text { boa imagem, e vice-versa) }\end{array}$ \\
\hline & Freqüência (dar continuidade a determinada cobertura) \\
\hline & $\begin{array}{l}\text { Formato (seguir uma formatação padrão }- \text { introdução, } \\
\text { desdobramento e conclusão - de acordo com o veículo) }\end{array}$ \\
\hline \multirow{2}{*}{ Relativas ao público } & $\begin{array}{l}\text { Estrutura narrativa (deve ser clara para o receptor, por isso a } \\
\text { importância que saber para quem estamos escrevendo) }\end{array}$ \\
\hline & $\begin{array}{l}\text { Protetividade (evitar notícias que possam criar traumas } \\
\text { desnecessários, como um acidente trágico, por exemplo) }\end{array}$ \\
\hline \multirow{4}{*}{ Relativa à concorrência } & $\begin{array}{l}\text { Exclusividade ou furo (importância de ser o primeiro a narrar } \\
\text { determinado acontecimento) }\end{array}$ \\
\hline & $\begin{array}{l}\text { Geração de expectativas recíprocas (gerar expectativas, ou não, } \\
\text { quanto à publicação do mesmo fato pelo veículo concorrente) }\end{array}$ \\
\hline & $\begin{array}{l}\text { Desencorajamento sobre inovações (conservadorismo de } \\
\text { conteúdo, de acordo com o perfil do público leitor) }\end{array}$ \\
\hline & $\begin{array}{l}\text { Estabelecimento de padrões profissionais (os novos profissionais, } \\
\text { assim como os novos veículos, tendem a imitar o comportamento } \\
\text { dos mais velhos) }\end{array}$ \\
\hline
\end{tabular}

TABELA 2: Categorias dos valores-notícia

FONTE: Elaborado pela autora, a partir de Hohlfeldt (2007).

De forma simplificada, podemos dizer que a produção jornalística se define a partir do processo de seleção da informação, pelo gatekeeper (de acordo com os critérios de noticiabilidade, definidos através de valores-notícia), que o transforma em notícia. Este processo também sofre influência do ambiente organizacional e da cultura profissional. 
Os valores-notícia, conforme destacado anteriormente, estão relacionados entre si e precisam ser contextualizados no processo de produção. Wolf (2005), destaca três fases deste processo de produção da informação: a coleta, a seleção e a apresentação. A estas fases, Hohlfeldt acrescenta ainda a distribuição, "que implica na seleção daquilo que vai ser mais ou menos distribuído, atingindo a todos os veículos vinculados a uma determinada agência ou só a alguns deles" (HOHLFELDT, 2007, p. 214). Examinaremos melhor este processo no próximo item deste trabalho (Aplicações).

\section{Aplicações}

De acordo com Hohlfeldt (2007, p. 219),

do ponto de vista da teoria da comunicação, a hipótese de estudo é importante porque ajuda a entendermos o modo pelo qual a informação flui, neste caso, de uma fonte primeira para o intermediário ou mediador, que é o jornalista - profissional da informação - e deste até o receptor final.

Como já apresentado anteriormente, esta teoria será utilizada para: entender quais são os critérios utilizados pelo atendimento, para selecionar as informações disponíveis e transformá-las no briefing; e para auxiliar na construção do roteiro de questões das entrevistas em profundidade. Percorreremos o caminho da informação desde sua fonte primeira, que é o cliente, passando pelo mediador, que é o atendimento, e deste até o receptor final. Neste caso, como estamos trabalhando com as informações de briefing, trataremos como receptor final aqueles que recebem este documento, ou seja, os departamentos envolvidos no processo de produção de uma determinada campanha.

Adaptando a teoria original, podemos dizer que a produção publicitária se define a partir do processo de seleção da informação, pelo atendimento (de acordo com os argumentos disponíveis, definidos através de valores-briefing), que o transforma em briefing. Desta forma, o profissional de atendimento está associado à figura do gatekeeper; e a notícia, ao briefing. Os critérios de noticiabilidade relacionam-se aos argumentos que o atendimento considera mais relevantes (conforme as informações fornecidas pelo cliente), de acordo com os valores-briefing.

Os valores-briefing foram agrupados em cinco categorias, assim como os valoresnotícia, na hipótese de newsmaking. É importante destacar que o atendimento, ao elaborar o 
briefing, precisa pensar tanto no departamento de criação, por exemplo, que é o que vai receber o documento, como no consumidor do produto ou serviço do cliente.

No quadro elaborado abaixo, estamos considerando os valores que o atendimento julga importante transmitir para a criação, para que esta desenvolva a campanha publicitária ${ }^{6}$. Estes valores podem ser adaptados aos outros departamentos da agência, mas escolhemos a criação por ser o departamento que recebe o maior número de briefings.

\begin{tabular}{|c|c|}
\hline CATEGORIAS & \\
\hline \multirow{2}{*}{$\begin{array}{c}\text { Substantivas } \\
\text { (relação entre as } \\
\text { informações e seus } \\
\text { personagens - } \\
\text { atendimento, cliente, } \\
\text { agência e consumidor) }\end{array}$} & $\begin{array}{l}\text { Importância (grau de significação e importância da campanha } \\
\text { para a sociedade; quantidade de pessoas envolvidas, ou melhor, } \\
\text { beneficiadas pela campanha e suas consequências) }\end{array}$ \\
\hline & $\begin{array}{l}\text { Interesse (capacidade de entretenimento: a capacidade da } \\
\text { campanha atrair e prender a atenção do consumidor) }\end{array}$ \\
\hline \multirow{4}{*}{$\begin{array}{c}\text { Relativas ao produto } \\
\text { (relativas à campanha } \\
\text { que deverá ser elaborada } \\
\text { pela criação) }\end{array}$} & $\begin{array}{l}\text { Brevidade (adequação à verba do cliente e adequação ao formato } \\
\text { do veículo, caso ele tenha sido definido anteriormente à criação) }\end{array}$ \\
\hline & $\begin{array}{l}\text { Atualidade (relação com o tempo de produção e veiculação, se há } \\
\text { possibilidade de criar e produzir uma peça ou não, em função do } \\
\text { dead line para impressão, por exemplo) }\end{array}$ \\
\hline & $\begin{array}{l}\text { Qualidade (qualidade técnica compatível com o nível de produto } \\
\text { ou serviço oferecido pelo cliente aos seus consumidores) }\end{array}$ \\
\hline & $\begin{array}{l}\text { Equilíbrio (saber conciliar determinadas características do texto } \\
\text { publicitário, como o humor, por exemplo, às necessidades do } \\
\text { cliente - informação demais é desnecessária) }\end{array}$ \\
\hline \multirow{3}{*}{$\begin{array}{c}\text { Relativas aos meios de } \\
\text { informação } \\
\text { (relacionadas ao veículo } \\
\text { e ao tempo de veiculação } \\
\text { da campanha) }\end{array}$} & $\begin{array}{l}\text { Bom material visual } \mathrm{x} \text { texto verbal (um bom texto deve ter uma } \\
\text { boa imagem, e vice-versa) }\end{array}$ \\
\hline & $\begin{array}{l}\text { Frequiência (dar continuidade a determinada campanha; em } \\
\text { muitos casos, uma campanha sem continuidade perde o sentido) }\end{array}$ \\
\hline & $\begin{array}{l}\text { Formato (seguir uma formatação padrão - de acordo com o } \\
\text { veículo; conhecer as normas técnicas de cada publicação é } \\
\text { fundamental) }\end{array}$ \\
\hline
\end{tabular}

\footnotetext{
${ }^{6}$ Nesta adaptação, retiramos o item Condições de desvio da informação, da categoria relativa ao produto, por entendermos que, no caso do processo de produção publicitária, ele se torna irrelevante.
} 


\begin{tabular}{|c|c|}
\hline \multirow{2}{*}{$\begin{array}{l}\text { Relativas ao público } \\
\text { (público do cliente: } \\
\text { consumidor) }\end{array}$} & $\begin{array}{l}\text { Estrutura narrativa (deve ser clara para o consumidor, por isso a } \\
\text { importância de saber para quem estamos escrevendo, para quem } \\
\text { estamos oferecendo o produto ou serviço do cliente) }\end{array}$ \\
\hline & $\begin{array}{l}\text { Protetividade (evitar campanhas que possam levantar polêmicas } \\
\text { ou repulsa por parte dos consumidores) }\end{array}$ \\
\hline \multirow{4}{*}{$\begin{array}{l}\text { Relativa à concorrência } \\
\text { (neste caso, a } \\
\text { concorrência pode ser o } \\
\text { depto. de criação de } \\
\text { outras agências, como os } \\
\text { concorrentes do próprio } \\
\text { cliente) }\end{array}$} & $\begin{array}{l}\text { Exclusividade (importância de ser o primeiro a trabalhar } \\
\text { determinado tema, ou o primeiro a utilizar uma determinada } \\
\text { tecnologia para anunciar) }\end{array}$ \\
\hline & $\begin{array}{l}\text { Geração de expectativas recíprocas (gerar expectativas, ou não, } \\
\text { quanto à veiculação de uma campanha, com o mesmo tema, pelo } \\
\text { cliente concorrente) }\end{array}$ \\
\hline & $\begin{array}{l}\text { Desencorajamento sobre inovações (conservadorismo de } \\
\text { conteúdo ou tecnologias, de acordo com o perfil do cliente e do } \\
\text { consumidor) }\end{array}$ \\
\hline & $\begin{array}{l}\text { Estabelecimento de padrões profissionais (os novos profissionais, } \\
\text { assim como os novos veículos, tendem a imitar o comportamento } \\
\text { dos mais velhos) }\end{array}$ \\
\hline
\end{tabular}

TABELA 3: Categorias dos valores-briefing.

FONTE: Elaborado pela autora.

Os valores-briefing estão relacionados entre si e precisam ser contextualizados no processo de produção. Este processo consiste nas fases de coleta, seleção e apresentação.

A fase de coleta, para o atendimento, está relacionada à busca das informações junto ao cliente, e também através de outras fontes. A solicitação inicial de um trabalho, pelo cliente, se dá através de, pelo menos, uma reunião formal com o atendimento, onde são discutidas as necessidades da campanha ou peça publicitária. A partir destas informações, o atendimento pode consultar outras fontes para complementar o trabalho (pesquisas de mercado, veículos, concorrência, opinião de consumidores, entre outras).

A partir desta fase de coleta, o profissional inicia o processo de seleção; dentre todas as informações recolhidas, e de acordo com os valores-briefing, ele vai elaborar o documento com a solicitação de trabalho, conforme os critérios de argumentação que ele julgar mais interessante para a criação da campanha (manteremos aqui, como exemplo, a relação com a criação). Ao final deste processo temos, então, o documento pronto, o briefing, que será apresentado à criação que, por sua vez, dará início ao seu trabalho. 
Assim, determinados os valores-briefing e conhecendo as fases do processo de produção, vamos à segunda etapa deste artigo, que é a elaboração do roteiro para as entrevistas em profundidade (a serem aplicadas futuramente na elaboração da dissertação de mestrado da autora).

As questões foram pensadas e elaboradas a partir dos pressupostos teóricos apresentados neste trabalho (comunicação e lugar/não-lugar), e das considerações de Silva \& Toaldo (2010, p. 128), que dizem o seguinte:

\begin{abstract}
Outro aspecto que pode afetar o relacionamento entre comprador e fornecedor são os erros sucessivos, decorrentes de problemas nos processos, falhas na comunicação entre as pessoas responsáveis pelo cliente, interpretação inadequada do briefing. Esses erros na publicidade obrigam a refazer o trabalho já realizado, o que gera descontentamento no cliente e pode gerar a perda de oportunidade de negócios, pois os prazos vão sendo alargados. Além disso, as equipes envolvidas ficam insatisfeitas, porque investiram tempo e energia, e ninguém, conscientemente, deseja produzir algo para ser rejeitado.
\end{abstract}

Como destacamos anteriormente, não basta informar para comunicar; o processo de comunicação que deve ser estabelecido pelo atendimento vai além da informação contida no briefing. A comunicação é a relação que este profissional estabelece com os demais departamentos, ou seja, é o reconhecimento e o respeito pelo outro. E é a partir desta relação que o atendimento constrói seus vínculos e determina (ou não) o seu lugar na organização; lugar que pressupõe identificação e significado como o espaço no qual este profissional atua.

Assim, consideramos importantes as seguintes questões:

\begin{tabular}{|l|l|}
\hline \multicolumn{2}{|c|}{ Roteiro / Questões } \\
\hline \multirow{2}{*}{} & $\begin{array}{l}\text { 1. Como se dá o processo de comunicação no teu dia-a-dia? Como acontece } \\
\text { a transmissão de informações e para quais públicos / departamentos elas } \\
\text { são transmitidas (onde começa e onde termina)? Existem ruídos nestes } \\
\text { processos? }\end{array}$ \\
\cline { 2 - 3 } & $\begin{array}{l}\text { 2. O processo de comunicação com o cliente acontece com entendimento } \\
\text { de ambas as partes? O cliente sabe, ou conhece, claramente o que quer } \\
\text { vender, para quem quer vender? }\end{array}$ \\
\cline { 2 - 3 } Relativas à & $\begin{array}{l}\text { 3. Quais os critérios utilizados para a elaboração de um briefing? Quais } \\
\text { conhecimentos técnicos o atendimento deve possuir para a realização deste } \\
\text { trabalho? E que outros conhecimentos destacaria como relevantes para esta } \\
\text { Comunicação }\end{array}$ \\
\hline \hline
\end{tabular}




\begin{tabular}{|c|c|}
\hline & $\begin{array}{l}\text { 4. Quais elementos você destacaria como os mais importantes no processo } \\
\text { de produção de uma campanha ou peça publicitária? Qual a interferência } \\
\text { do atendimento? }\end{array}$ \\
\hline & $\begin{array}{l}\text { 5. Que características/habilidades considera essenciais para a função de } \\
\text { atendimento? }\end{array}$ \\
\hline \multirow{8}{*}{$\begin{array}{l}\text { Relativas à } \\
\text { Lugarização }\end{array}$} & $\begin{array}{l}\text { 6. Como a questão tempo interfere nas rotinas publicitárias? Que } \\
\text { considerações tens a fazer sobre isto? }\end{array}$ \\
\hline & $\begin{array}{l}\text { 7. Já ouvimos algumas vezes que o atendimento, ou está do lado da } \\
\text { agência, ou do lado do cliente. Isso acontece? De que forma? Como } \\
\text { administrar? }\end{array}$ \\
\hline & $\begin{array}{l}\text { 8. Quais são as relações (de trabalho / profissional / interpessoal) } \\
\text { estabelecidas entre você e o cliente, você e a agência? Existem relações } \\
\text { pessoais? É possível separá-las? Entram em conflito? }\end{array}$ \\
\hline & $\begin{array}{l}\text { 9. Qual sua opinião sobre a rotatividade dos profissionais nas agências? } \\
\text { Existe alguma dificuldade em estabelecer vínculos com as empresas? Quais } \\
\text { seriam os motivos para isso acontecer? }\end{array}$ \\
\hline & $\begin{array}{l}\text { 10. Existe diferença entre a cultura da agência e a do cliente? E a diferença } \\
\text { com a sua cultura (social, cultural, valores, princípios, etc.)? Em algum } \\
\text { momento, elas entram em conflito ou influenciam a sua cultura/identidade? } \\
\text { Com qual delas você se identifica mais e por quê? }\end{array}$ \\
\hline & $\begin{array}{l}\text { 11. Que tipo de conduta ética o atendimento deve adotar em relação ao } \\
\text { cliente e em relação a agência? Existe algum tipo de norma a ser seguida? } \\
\text { Algum tipo de informação (ou atitudes, posturas, etc.) que deva ser omitida } \\
\text { da agência e/ou do cliente? Se puder falar um pouco sobre a questão da } \\
\text { ética nesta profissão (atendimento)... }\end{array}$ \\
\hline & $\begin{array}{l}\text { 12. Já houve casos em que você discordou da agência ou do cliente? Ou } \\
\text { conhece algum caso? (Em qualquer situação: pedido de trabalho, } \\
\text { solicitação para criação, postura profissional, etc.). Como dizer não para } \\
\text { uma solicitação? Comentar/Exemplificar. }\end{array}$ \\
\hline & 13. Você se considera satisfeito com sua profissão? Que aspectos mudaria? \\
\hline
\end{tabular}

TABELA 4: Roteiro para entrevistas em profundidade com os profissionais de atendimento.

FONTE: Elaborado pela autora. 
É com este roteiro que pretendemos alcançar os objetivos da dissertação de mestrado: analisar as relações de trabalho estabelecidas entre o profissional de atendimento e seus diferentes públicos (cliente e agência), a partir das rotinas publicitárias; e investigar como estas rotinas de produção (coleta, seleção e apresentação) e seus decorrentes processos de comunicação interferem na construção de vínculos entre estes profissionais e as organizações em que atuam, isto é, como o atendimento se lugariza (ou não), no desenrolar deste processo.

\section{Algumas considerações}

Trabalhar com a hipótese de newsmaking, muito utilizada pelas pesquisas no campo do jornalismo, abre caminhos para uma visão diferenciada do mercado publicitário. Sendo assim, as rotinas de produção e o estudo dos emissores, que são campos ainda pouco explorados na pesquisa publicitária acadêmica, poderão qualificar-se através desta abordagem.

Comunicação e vínculos, que resultam na lugarização (ou não) dos profissionais de atendimento nas agências em que atuam, foram os caminhos teóricos escolhidos para a elaboração deste trabalho. Como citado anteriormente, trabalho que faz parte do projeto de dissertação de mestrado, e que está em fase inicial. Concluir uma etapa seria privá-la de outros olhares e outras possibilidades que surgem constantemente no decorrer da pesquisa.

\section{Referências Bibliográficas}

AUGÉ, Marc. Não-lugares: introdução a uma antropologia da supermodernidade. Campinas: Papirus, 1994.

BAUMAN, Zygmunt. Modernidade líquida. Rio de Janeiro: Jorge Zahar, 2001.

CASTRO, Maria Lília Dias de. "Práticas publicitárias: O embaralhamento do discurso promocional". In: CASTRO, Maria Lília Dias de; DUARTE, Elisabeth Bastos (Orgs.). Em torno das mídias: práticas e ambiências. Porto Alegre: Sulina, 2008, p. 41-53.

FISCHER, Gustave-Nicolas. "Espaço, identidade e organização". In: CHANLAT, JeanFrançois (Coord.). O indivíduo na organização. Vol. 2. São Paulo: Atlas, 1994, p. 39-79.

HOHFELDT, Antonio. "Hipóteses contemporâneas de pesquisa em comunicação". In: HOHLFELDT, Antonio; MARTINO, Luiz C.; FRANÇA, Vera Veiga (Orgs.). Teorias da comunicação: conceitos, escolas e tendências. 7 ed. Petrópolis: Vozes, 2007, p. 187-240. 
IASBECK, Luiz Carlos Assis. "A cultura e o discurso da cultura nos contextos organizacionais". In: MARCHIORI, Marlene (Org.). Faces da cultura e da comunicação organizacional. São Caetano do Sul: Difusão, 2010, p. 137-149.

MARCONDES FILHO, Ciro. Para entender a comunicação: contatos antecipados com a nova teoria. São Paulo: Paulus, 2008.

MORIN, Edgar; CLOTET, Joaquim; SILVA, Juremir Machado da. As duas globalizações: complexidade e comunicação, uma pedagogia do presente. 3 ed. Porto Alegre: Sulina, 2007.

SAMPAIO, Rafael. Propaganda de A a Z: como usar a propaganda para construir marcas e empresas de sucesso. 2 ed. Rio de Janeiro: Campus/ABP, 1999.

SANT'ANNA, Armando; GARCIA, Luiz Fernando Dabul; ROCHA JÚNIOR, Ismael. Propaganda: teoria, técnica e prática. 8 ed. São Paulo: Cengage Learning, 2010.

SANTAELLA, Lucia. Linguagens líquidas na era da mobilidade. São Paulo: Paulus, 2007.

SILVA, Iara Silva da; TOALDO, Mariângela Machado. Publicitários + anunciantes: a dinâmica de uma relação complexa. Porto Alegre: Entremeios, 2010.

WOLF, Mauro. Teorias das comunicações de massa. 2 ed. São Paulo: Martins Fontes, 2005.

WOLTON, Dominique. Informar não é comunicar. Porto Alegre: Sulina, 2010.

É preciso salvar a comunicação. São Paulo: Paulus, 2006. 